\title{
Thiourea and Methylthiouracil as Supplements in Rations of Fattening Pigs
}

\author{
BY R. BRAUDE \\ National Institute for Research in Dairying, University of Reading \\ AND E. COTCHIN \\ Research Institute in Animal Pathology, Royal Veterinary College, \\ Camden Town, London, N.W. I \\ (Received 23 February 1949)
}

Thiourea and its derivatives are drugs known to have an inhibitory effect on the activity of the thyroid gland (cf. Astwood, I943; Mackenzie \& Mackenzie, 1943; Mixner, Reineke \& Turner, 1944; Charipper \& Gordon, 1947). Hypothyroidism is a condition associated with a decrease in metabolic rate and with obesity. In pig feeding the ability to produce at will, by varying the nutritional plane and quality of the ration, either a bacon or a lard pig is usually ascribed to the effect of the food on the metabolic rate of the animal. It thus appeared possible so to influence the carcass quality by feeding antithyroid drugs to pigs as to obtain carcasses suitable for the various market requirements for the proportion of fat to lean in pork and bacon. The possibility of achieving improved food utilization by the animal was also envisaged.

Muhrer \& Hogan (1945) concluded from the results of their experiment that thiouracil added at the rate of $2 \%$ of the ration, produced after 28 days 'shorter and fatter pigs than controls'. The test animals were less active but gained weight more rapidly and more economically. Vander Noot, Reece \& Skelley (1947) reported that by including $0.25 \%$ of thiouracil in the ration of pigs weighing about $200 \mathrm{lb}$. for a period of $38-45$ days they improved the rate of growth and food utilization. The same authors (Vander Noot et al. 1948) reported that $0.25 \%$ of thiouracil fed to Duroc Jersey and Berkshire pigs from weaning onwards produced untoward effects, and concluded that it should not be fed to pigs until they had reached the desired skeletal development. Once that was attained the thiouracil supplement would cause an improvement in the rate of gain and in food utilization.

McMillen, Reineke, Bratzler \& Francis (1947) fed 0.1\% thiouracil to Chester White and Yorkshire pigs, the treatment commencing when the pigs averaged $162 \mathrm{lb}$. live weight and continuing for 6 weeks. Their results indicated that, as compared with that of controls, the growth rate of the treated pigs was slightly reduced, and the food utilization markedly improved. Although only a small number of animals was used the results suggested a possible variation in response to thiouracil treatment between breeds, and also seasonal effects. The authors found, however, no significant differences in the carcass quality that could be attributed to thiouracil treatment.

Acevedo, Schweigert, Pearson \& Dahlberg (1948) fed $0.25 \%$ thiouracil to Hampshire and Duroc Jersey pigs whose initial weight varied from I 14 to $187 \mathrm{lb}$. Their results 
indicated that the growth rate was very markedly depressed and the food intake and food utilization were lowered in the treated animals. No significant differences in carcass quality were observed, but a marked breed difference was noted. Similarly, Willman, Loosli \& Klosterman (1946) found that either 0.1 or $0.2 \%$ thiouracil included in the ration slowed up the rate of gain and decreased the economy of food utilization.

As far as other species of domestic livestock are concerned, Kempster \& Turner (1945), by feeding $0.2 \%$ of thiouracil to broiler chicks for $3^{6}$ days, reduced the rate of growth and increased the amount of feed required to produce a pound of gain 'but greatly improved the grade'. Feeding thiouracil for a $16-$ day period resulted in improvement of grade without reduction of growth rate. Similar results were reported by Andrews \& Schnetzler (1946) and Glazener \& Jull (1946).

Andrews, Beeson, Barrick \& Harper (1947) fed different levels of thiourea and thiouracil to lambs, and reported that thiourea when fed at levels ranging from 0.048 to $0.07 \mathrm{I} \mathrm{g}$./lamb daily significantly depressed growth. Thiouracil, on the other hand, when fed at levels ranging from 0.175 to $0.544 \mathrm{~g}$. had no significant effect on the rate of growth. Both drugs proved very unpalatable. The feed requirements per $\mathrm{lb}$. gain were not affected by the lower doses, but when the daily dose exceeded $0.333 \mathrm{~g}$. an adverse effect was noted. Lambs receiving 0.175 and $0.333 \mathrm{~g}$. of thiouracil daily produced carcasses of better quality.

Working with steers, Beeson, Andrews \& Brown (1947) recorded that the live-weight gain, the food utilization and the carcass quality were slightly, but not significantly, improved in groups receiving 2 or $4 \mathrm{~g}$. daily of the drug. The thiouracil-fed cattle appeared more docile, less active and less subject to excitement.

The experiments described below were carried out with the aim of investigating the various effects of antithyroid drugs on fattening pigs under conditions prevailing in this country.

\section{EXPERIMENT I. EFFECT OF THIOUREA}

\section{Methods}

Groups of four weaners were selected from four Large White litters of our own breeding, and divided in such a way that each litter was represented by one pig in each of the four experimental groups. Although there was some variation between the litters all the litter-mates were uniform in respect of sex and initial weight.

Each group occupied a pen provided with small individual feeding compartments into which the animals were allowed twice daily for about $30 \mathrm{~min}$. to eat their food. They were fed a meal mixture consisting of wheat feed 47 , barley meal 20 , ground oats 20, dried grass 3 and white-fish meal 10\%. Once weekly a small amount of codliver oil was added directly to the troughs. The pigs were weighed three times a week and the quantity of food given was adjusted for live weight after each weighing, according to a normal scale for fattening pigs (cf. Braude \& Foot, 1942). The meal was weighed out and fed twice daily as a wet mash, $3 \mathrm{lb}$. of water being allowed for $\mathrm{I} \mathrm{lb}$. of meal.

'The original plan of the experiment included four treatments. Group I was the control group, in which the pigs were to receive the meal mixture without any supple- 
ment. In group 2, the pigs were to receive the meal mixture and $1.5 \mathrm{~g}$. daily of thiourea/100 lb. live weight. In group 3 , this supplement was to be reduced to $0.75 \mathrm{~g}$. and in group 4 to $0.375 \mathrm{~g}$. The thiourea was added directly to the trough in a suspension in distilled water, the amount given being adjusted according to live weight after each weighing of the pigs.

After 22 days, it became obvious that, owing to the very bitter taste of the thiourea, the pigs would not consume the meal to which it was added. All the thiourea supplements were then discontinued and the pigs were allowed to recover from the setback. After 15 days, when they appeared normal again and were consuming the meal allotted to them, the experimental treatment was resumed, but the supplements, instead of being added to the food, were given as a drench. This period lasted 16 days. The handling of pigs for drenching badly upset a number of them, independently of treatment, especially during the first few days before they became accustomed to it. It was thought advisable at this stage to give them another rest period of 17 days during which the pigs were handled as for drenching but not actually drenched. This was followed by a I6-day period during which the pigs in the experimental groups were drenched again, but this time with double the amount, namely daily with $3 \cdot 0, \mathrm{I} \cdot 5$ and $0.75 \mathrm{~g}$. thiourea/ I00 lb. live weight, respectively. By this time the pigs were used to the handling associated with drenching. It appeared also that they had become accustomed to the bitter taste of the supplement. It was then decided to put them, after a r6-day rest period, back on the original treatment in which the supplements were added to the food. As no detrimental effects were observed at this stage the amount of supplement added to the food was doubled. This final period lasted 30 days. Thus, there were eight experimental periods in all, as shown in Table $\mathrm{I}$.

\section{Results}

Table 1 gives details of the rate of growth, food intake and food utilization. During the first period when thiourea was mixed with the food the pigs refused a considerable proportion of the food offered. The higher the amount of thiourea the more frequent and more substantial were the refusals. During this period the control pigs grew at a fairly normal rate, but the growth rate of the treated pigs was decreased. The severity of the effect on growth and on food utilization was roughly proportional to the amount of thiourea fed.

During the rest period which followed, all the pigs returned to normal, and at the end of this period no significant refusal of food was observed in any of the groups.

In the next period some pigs, irrespective of group, were affected by the handling associated with drenching. The pigs had to be caught by two men and held by their forelegs in a suitable position for drenching, a procedure to which they strongly objected. Quite often, the pigs struggled and some were upset more than others. It happened that the pigs receiving the smallest dose of thiourea were the least affected, even less than the controls. It was, however, noticed that the pigs gradually became accustomed to the handling. During the next period the handling was continued but no thiourea was given to any of the groups. Table I shows that the pigs soon returned to normal and both growth and food utilization became satisfactory. 
Table I. Exp. I. Growth, food intake and food utilization of groups of four pigs receiving thiourea

\begin{tabular}{|c|c|c|c|c|c|c|c|}
\hline \multicolumn{2}{|c|}{ Period } & \multirow{2}{*}{$\begin{array}{l}\text { Method of } \\
\text { administration } \\
\text { of the drug }\end{array}$} & \multirow{2}{*}{$\begin{array}{l}\text { Total live- } \\
\text { weight gain } \\
\text { of group } \\
\text { (lb.) }\end{array}$} & \multirow{2}{*}{$\begin{array}{l}\text { Food } \\
\text { consumed } \\
\text { (lb.) }\end{array}$} & \multicolumn{2}{|c|}{ Food refusals } & \multirow{2}{*}{$\begin{array}{r}\text { Food } \\
\text { eaten/lb } \\
\text { live-weig } \\
\text { gain } \\
\text { (lb.) }\end{array}$} \\
\hline \multirow[t]{2}{*}{ No. } & $\begin{array}{l}\text { Length } \\
\text { (days) }\end{array}$ & & & & $\begin{array}{l}\text { No. of } \\
\text { occasions }\end{array}$ & $\underset{\text { (lb.) }}{\text { Amount }}$ & \\
\hline & & & Group I. & Control & & & \\
\hline I & 22 & Not given & 84 & 217 & 14 & 4.9 & $2 \cdot 6$ \\
\hline 2 & 15 & Not given & 55 & 183 & 12 & $4 \cdot 6$ & $3 \cdot 3$ \\
\hline 3 & 16 & Not given & $3^{6}$ & 210 & 24 & 247 & 5.8 \\
\hline 4 & 17 & Not given & 65 & 235 & 30 & $25 \cdot 6$ & $3 \cdot 6$ \\
\hline 5 & 16 & Not given & 79 & 277 & 10 & 10.6 & 3.5 \\
\hline 6 & 16 & Not given & 86 & 319 & 13 & $12 \cdot 8$ & 3.7 \\
\hline 7 & 17 & Not given & 93 & 392 & I & $2 \cdot 4$ & $4 \cdot 2$ \\
\hline 8 & 30 & Not given & $16 I$ & 772 & 6 & 12.5 & $4 \cdot 8$ \\
\hline Total & 149 & & 659 & 2605 & I10 & $98 \cdot I$ & $4^{\circ} 0$ \\
\hline \multicolumn{3}{|c|}{ Mean final weight of pig } & $206 \cdot 0$ & & & & \\
\hline
\end{tabular}

Mean final weight of pig

Group 2. Thiourea I.5-3.0 g./100 lb. live weight

\begin{tabular}{|c|c|c|c|c|c|c|c|}
\hline I & 22 & Fed & 46 & 170 & 54 & 30.5 & $3 \cdot 7$ \\
\hline 2 & 15 & Not given & 49 & 145 & 25 & 12.5 & $3 \cdot 0$ \\
\hline 3 & 16 & Drenched & 33 & $17 \mathbf{I}$ & 32 & $22 \cdot 3$ & $5 \cdot 2$ \\
\hline 4 & 17 & Not given & 65 & 204 & 23 & $21 \cdot 9$ & $3 \cdot I$ \\
\hline 5 & 16 & $\begin{array}{l}\text { Drenched with } \\
\text { double dose }\end{array}$ & 72 & 241 & 9 & $9 \cdot 0$ & $\mathbf{3} \mathbf{3}$ \\
\hline 6 & 16 & Not given & 83 & 290 & 5 & $3 \cdot 0$ & $3 \cdot 5$ \\
\hline 7 & 17 & Fed & 92 & 344 & 12 & $13 \cdot 9$ & $3 \cdot 7$ \\
\hline 8 & 30 & $\begin{array}{l}\text { Fed, double } \\
\text { dose }\end{array}$ & 134 & 489 & 107 & $244^{\circ}$ & 3.6 \\
\hline Total & I49 & & 574 & 2054 & 267 & $357^{\prime} \mathrm{I}$ & $3 \cdot 6$ \\
\hline \multicolumn{3}{|c|}{ Mean final weight of pig } & 180.5 & & & & \\
\hline
\end{tabular}

Group 3. Thiourea $0.75-1 \cdot 5 / 100 \mathrm{lb}$. live weight

\begin{tabular}{|c|c|c|c|c|c|c|c|}
\hline $\mathbf{I}$ & 22 & Fed & 53 & 200 & 42 & $25 \cdot 7$ & $3 \cdot 8$ \\
\hline 2 & 15 & Not given & $5 \mathrm{I}$ & 159 & 27 & 15.9 & 3.I \\
\hline 3 & 16 & Drenched & 36 & 178 & $4 I$ & $32 \cdot 4$ & 4.9 \\
\hline 4 & I7 & Not given & 75 & 236 & 20 & 15.6 & $3 \cdot 2$ \\
\hline 5 & 16 & $\begin{array}{l}\text { Drenched with } \\
\text { double dose }\end{array}$ & 70 & 257 & 17 & $18 \cdot 9$ & 3.7 \\
\hline 6 & 16 & Not given & 57 & 269 & 28 & $40 \cdot 0$ & 4.7 \\
\hline 7 & 17 & Fed & 80 & 329 & 23 & $38 \cdot 0$ & $4 \cdot 1$ \\
\hline 8 & 30 & $\begin{array}{l}\text { Fed, double } \\
\text { dose }\end{array}$ & I $3 \mathbf{I}$ & 565 & 85 & $176 \cdot 0$ & $4 \cdot 3$ \\
\hline Total & 149 & & 553 & 2193 & 283 & $3^{62 \cdot 5}$ & $4 \cdot 0$ \\
\hline \multicolumn{3}{|c|}{ Mean final weight of pig } & $181 \cdot 8$ & & & & \\
\hline
\end{tabular}

Group 4. Thiourea $0.375-0.75 \mathrm{~g} / 100 \mathrm{lb}$. live weight

\begin{tabular}{|c|c|c|c|c|c|c|c|}
\hline I & 22 & Fed & 62 & 195 & $3^{8}$ & 15.9 & $3 \cdot 2$ \\
\hline 2 & 15 & Not given & 45 & 157 & 24 & 14.9 & $3 \cdot 5$ \\
\hline 3 & 16 & Drenched & 52 & $\times 87$ & 25 & $15 \cdot 2$ & 3.6 \\
\hline 4 & 17 & Not given & 72 & 239 & II & $11 \cdot 4$ & $3 \cdot 3$ \\
\hline 5 & 16 & $\begin{array}{l}\text { Drenched with } \\
\text { double dose }\end{array}$ & 75 & 278 & 4 & 3.9 & 3.7 \\
\hline 6 & 16 & Not given & 73 & 294 & I3 & $21 \cdot 9$ & 4.0 \\
\hline 7 & 17 & Fed & 98 & 376 & 8 & $7 \cdot 6$ & 4.2 \\
\hline 8 & 30 & $\begin{array}{l}\text { Fed, double } \\
\text { dose }\end{array}$ & 171 & $76_{3}$ & 9 & $11 \cdot 0$ & 4.5 \\
\hline Total & 149 & & 648 & 2489 & 132 & $101 \cdot 8$ & 3.8 \\
\hline \multicolumn{3}{|c|}{ Mean final weight of pig } & 200 & & & & \\
\hline
\end{tabular}


During the fifth period the pigs objected very little, or not at all, to being handled. In spite of the relatively high doses with which some of the pigs were drenched no detrimental effect of thiourea was observed. All the pigs, both controls and treated, grew at a normal rate and ate and utilized the food satisfactorily.

At this stage a 16-day control period was introduced during which all groups were fed the normal diet. One pig in group 3 , for no obvious reasons, behaved abnormally during the early part of this period. Its abnormal behaviour was responsible for the high food refusals and a corresponding low gain for the group. It should be noted that this pig started to behave abnormally towards the end of the preceding period and did not completely recover during the control period.

In the seventh period the rate of gain, food intake and food utilization appeared normal in all the groups. The abnormal pig in group 3, which during the early part of this period was lagging behind, completely recovered by the end of this period.

After 17 days the amount of thiourea added to the food was doubled. By this time the pigs in the experimental groups were weighing more than $150 \mathrm{lb}$. each, which meant that pigs in group 2 received as much as $4.5 \mathrm{~g}$. of thiourea daily, and the pigs in the other groups corresponding amounts. During this period, which lasted 30 days, pigs in groups 2 and 3 refused to consume the food offered them, and accordingly their rate of growth was adversely affected. The pigs in group 4 , which received the lowest dose of thiourea, appeared to be unaffected by the treatment.

In Table I the appropriate values for the whole experimental period lasting 149 days are shown. From the results it appears that the differences between the groups were caused by refusal of the pigs to consume meal containing appreciable amounts of the very bitter thiourea. After a time the animals became accustomed to a small quantity of the drug and appeared to tolerate it. It seemed possible that certain levels of the drug in the diet improved the utilization of food, but further evidence on this was required.

Table 2. Exp. I. Mean values for carcass measurements of groups of four pigs listed in Table I

\begin{tabular}{|c|c|c|c|c|}
\hline & $\begin{array}{l}\text { Group I } \\
\text { Control }\end{array}$ & $\begin{array}{l}\text { Group } 2 \\
\text { High thiourea }\end{array}$ & $\begin{array}{c}\text { Group } 3 \\
\text { Medium thiourea }\end{array}$ & $\begin{array}{c}\text { Group } 4 \\
\text { Low thiourea }\end{array}$ \\
\hline Final live weight (lb.) & $206 \cdot 0$ & 180.5 & $181 \cdot 8$ & $200 \cdot 5$ \\
\hline Hot carcass weight (lb.) & $152 \cdot 0$ & $129 \cdot 5$ & $133 \cdot 0$ & $146 \cdot 3$ \\
\hline Killing out percentage & $73 \cdot 8$ & $71 \cdot 7$ & $73 \cdot 2$ & $73 \cdot 0$ \\
\hline Length of body cavity (mm.) & 927 & $86 I$ & 879 & 896 \\
\hline Length of hind leg (mm.) & 588 & 562 & 576 & 586 \\
\hline Thickness of back fat $(A)(\mathrm{mm})$. & $50 \cdot 5$ & $42 \cdot 0$ & $4 I \cdot 3$ & $45^{\circ} \circ$ \\
\hline Thickness of back fat $(B)(\mathrm{mm})$. & $24 \% 3$ & 15.8 & $21 \cdot 8$ & $20 \cdot 5$ \\
\hline $\begin{array}{l}\text { Thickness of rump fat } \\
\left(C_{1}, C_{2}, C_{2}\right)(\mathrm{mm} .)\end{array}$ & $32 \cdot 8$ & $21 \cdot 8$ & $25 \cdot 4$ & $28 \cdot 2$ \\
\hline
\end{tabular}

Table 2 gives data for carcass measurements. The method of Davidson, Hammond, Swain \& Wright (1936) was used for measuring carcass quality. Owing to the small number of animals in each group definite conclusions are not justified. It may, however, be noted that the carcasses of control pigs were longer and leaner than those described by Davidson et al. (1936) and Hammond \& Murray (1937). As the trial was 
conducted during a period of scarcity and low quality of feeding-stuffs our pigs were most probably older when they reached a particular weight level. When the variation in the final weights of our pigs is taken into account, there are no striking differences in the carcass measurements between the groups receiving different treatments. The data suggest that the high thiourea treatment produced a slightly shorter carcass and adversely affected the deposition of fat, but the evidence is not conclusive.

Sections of thyroid glands from the pigs in this experiment were prepared by Dr E. G. White. Histologically, the thyroid glands of the treated pigs showed hyperplasia, marked in those pigs receiving the higher doses of thiourea, and only slight in the group receiving the small amount.

\section{EXPERIMENT 2. EFFECT OF METHYLTHIOURACIL}

In the first experiment the bitterness of thiourea was found mainly responsible for the refusal by the pigs to consume a diet containing the drug. It was then suggested to us that methylthiouracil might be more satisfactory for further experimentation, as it is much less bitter, and also its bitterness is not preceded by a sulphurous taste which makes the taste of thiourea for man positively revolting. In its action on the thyroid methylthiouracil is more potent than thiourea, and thus smaller doses would be needed. Work was therefore continued with methylthiouracil, very kindly put at our disposal by Messrs May and Baker Ltd., Dagenham.

\section{Methods}

Three groups consisting of six weaners each, similar in sex, litter origin and initial weight were used. One group, chosen by lot, acted as a control group; pigs in group 2 received daily $2 \mathrm{~g}$., and those in group $3 \mathrm{I}$ g., of methylthiouracil//100 lb. live weight. The drug was added directly to the troughs at the afternoon feeding. The ration fed and the experimental routine followed were as for Exp. 1 .

The treatment was discontinued after I I weeks. Three pigs from each group were slaughtered at this stage, and the remaining few continued on a normal ration without any drug supplement for another 8 weeks.

At slaughter the thyroid glands of the pigs were removed and weighed, and paraffin sections were prepared for histological examination.

\section{Results}

Soon after the commencement of the experiment, one pig in group 3 behaved abnormally and was excluded from the test.

Table 3 gives details of the growth of the animals on each treatment and particulars of their food intake and food utilization. The growth rate and food utilization of the control pigs were satisfactory. During the I I weeks of treatment the rate of growth of the pigs receiving the high dose of methylthiouracil was adversely affected, and so was, but to a lesser degree, the rate of growth of the pigs receiving the lower level of the drug. From the food intake figures it is obvious that the difference in growth rate was due to variation in the amount of food consumed by the pigs. The treated animals 
refused a considerable portion of the food given. Whether this refusal was due to an objectionable taste, or whether it was caused by the drug depressing appetite, could not be ascertained.

Table 3. Exp. 2. Mean values for gain in weight, food intake and food utilization of pigs receiving methylthiouracil

Initial live weight (lb.)

\begin{tabular}{|c|c|c|c|c|c|c|c|c|}
\hline \multicolumn{3}{|c|}{$\begin{array}{c}\text { Group } 1 . \text { Control } \\
45.8\end{array}$} & \multicolumn{3}{|c|}{$\begin{array}{l}\text { Group 2. Methylthiouracil } \\
2 \mathrm{~g} . / 100 \mathrm{lb} \text {. Iive } \mathrm{wt} \text {. } \\
46.2\end{array}$} & \multicolumn{3}{|c|}{$\begin{array}{l}\text { Group 3. Methylthiouracil } \\
\text { I } \mathrm{g} \cdot / 100 \mathrm{lb} \text {. Iive wt. } \\
44^{\prime 2}\end{array}$} \\
\hline $\begin{array}{c}\text { First } \\
77 \text { days } \\
\text { (oix } \\
\text { pigos) }\end{array}$ & $\begin{array}{c}\text { Last } \\
56 \text { deys } \\
\text { (three } \\
\text { pigs) }\end{array}$ & $\begin{array}{l}\text { Period of } \\
133 \text { days } \\
\text { (three } \\
\text { pigs) }\end{array}$ & $\begin{array}{c}\text { First } \\
77 \text { days } \\
\text { (six } \\
\text { pigs) }\end{array}$ & $\begin{array}{c}\text { Last } \\
56 \text { days } \\
\text { (three } \\
\text { pigs) }\end{array}$ & $\begin{array}{l}\text { Period of } \\
\text { 133 days } \\
\text { (three } \\
\text { pigs) }\end{array}$ & $\begin{array}{l}\text { First } \\
77 \text { dinys } \\
\text { (aix } \\
\text { pigs) }\end{array}$ & $\begin{array}{c}\text { Laat } \\
56 \text { days } \\
\text { (three } \\
\text { piga) }\end{array}$ & $\begin{array}{l}\text { Period of } \\
133 \text { days } \\
\text { (three } \\
\text { piga) }\end{array}$ \\
\hline $\begin{array}{r}123 \cdot 7 \\
77 \cdot 9 \\
26 \times \cdot 1 \\
3 \cdot 3\end{array}$ & $\begin{array}{r}196.3 \\
72.6 \\
336.1 \\
4.6\end{array}$ & $\begin{array}{r}196.3 \\
150.5 \\
587.9 \\
3.9\end{array}$ & $\begin{array}{r}92.8 \\
46.6 \\
163.3 \\
3.5\end{array}$ & $\begin{array}{r}154.0 \\
61.2 \\
258.3 \\
4.1\end{array}$ & $\begin{array}{r}154.0 \\
107.8 \\
415.5 \\
3.9\end{array}$ & $\begin{array}{r}104.6 \\
60.4 \\
193.7 \\
3.2\end{array}$ & $\begin{array}{r}163.0 \\
58.4 \\
269.5 \\
4.6\end{array}$ & $\begin{array}{r}163.0 \\
118.8 \\
453.0 \\
3.8\end{array}$ \\
\hline $\begin{aligned} 16.6 \\
10.5 \\
4.0\end{aligned}$ & $\begin{array}{l}4 \cdot 0 \\
2 \cdot 3 \\
0 \cdot 7\end{array}$ & $\begin{array}{r}26 \cdot 0 \\
17.8 \\
3 \cdot 0\end{array}$ & $\begin{array}{l}58 \cdot 7 \\
54 \cdot 1 \\
33 \cdot 1\end{array}$ & $\begin{array}{l}9 \cdot 3 \\
8 \cdot 8 \\
3 \cdot 5\end{array}$ & $\begin{array}{l}67.6 \\
66.4 \\
\times 5.9\end{array}$ & $\begin{array}{l}53 \cdot 4 \\
51.7 \\
27 \cdot 0\end{array}$ & $\begin{array}{r}12 \cdot 5 \\
8 \cdot 2 \\
3 \cdot 1\end{array}$ & $\begin{array}{l}69.5 \\
66.5 \\
14.7\end{array}$ \\
\hline
\end{tabular}

When dosing with methylthiouracil was discontinued the rate of growth of pigs which previously received the high or low dose of methylthiouracil improved considerably. The difference between these two groups disappeared, but both lagged behind the control group. None of the pigs refused food. The pigs receiving the high dose of methylthiouracil utilized their food better during this period than the control pigs or the pigs receiving the lower dose. The food utilization figures for the whole experimental period ( 19 weeks) show very little difference between the groups.

Table 4. Exp. 2. Mean values for carcass measurements of groups of three pigs listed in Table 3

\begin{tabular}{|c|c|c|c|c|c|c|}
\hline & \multicolumn{2}{|c|}{$\begin{array}{c}\text { Group I } \\
\text { Control } \\
\text { After }\end{array}$} & \multicolumn{2}{|c|}{$\begin{array}{c}\text { Group 2 } \\
\text { Methylthiouracil } \\
\text { 2 g./100 lb. live wt. } \\
\text { After }\end{array}$} & \multicolumn{2}{|c|}{$\begin{array}{c}\text { Group 3 } \\
\text { Methylthiouracil } \\
\text { 1 8. } / \text { roo lb. live wt. } \\
\text { After }\end{array}$} \\
\hline & 11 weeks & I9 weeks & II weeks & I9 weeks & 11 weeks & 19 weeks \\
\hline $\begin{array}{l}\text { Final live weight } \\
\text { Hot carcass weight (lb) }\end{array}$ & $129 \cdot 0$ & $196 \cdot 3$ & $94 \cdot 3$ & I $54^{\circ} \circ$ & $107 \cdot 0$ & $163.0 t$ \\
\hline $\begin{array}{l}\text { Hot carcass weight (lb.) } \\
\text { Length of body cavity (mm.) }\end{array}$ & & 144.7 & & I $12 \cdot 3$ & - & $116.0 \dagger$ \\
\hline Length of body cavity (mm.) & $821 \cdot 0$ & $798 \cdot 0$ & 673 & $749 \cdot 0$ & 671 & 714.00 \\
\hline Length of hind leg (mm.) & $486 \cdot 0$ & $5^{85}$ & 416 & $342 \cdot 0$ & 437 & $544 \dagger$ \\
\hline $\begin{array}{l}\text { Thickness of back fat }(A) \\
(\mathrm{mm} .) \pm\end{array}$ & $33 \cdot 0$ & $49 \cdot 7$ & $30 \cdot 0$ & $43 \cdot 0$ & $29 \cdot 3$ & $44^{t}$ \\
\hline $\begin{array}{l}\text { Thickness of back fat }(B) \downarrow \\
\text { (mm.) }\end{array}$ & 13.7 & 25 & 10.7 & $19 \cdot 0$ & $13 \cdot 3$ & $2 \mathrm{It}$ \\
\hline $\begin{array}{l}\text { Thickness of rump fat } \\
\left(C_{1}, C_{2}, C_{3}\right)(\mathrm{mm} .) \downarrow\end{array}$ & $15 \cdot 8$ & $29 \cdot 1$ & $12 \cdot 1$ & $22 \cdot 2$ & 14.5 & $27 \cdot 3 \dagger$ \\
\hline Weight of thyroid (g.) & $5 \cdot 2$ & I8.7† & $30 \cdot 6$ & $29 \cdot 4$ & $30 \cdot 3$ & $36.9 \dagger$ \\
\hline
\end{tabular}

- Not available-owing to a mistake at the slaughter house.

$\dagger$ Two pigs only.

$\ddagger$ See footnote to 'Table 2.

Table 4 gives carcass measurement for the two lots of pigs, one slaughtered after II weeks of treatment and one after an additional 8 weeks of normal feeding. There is nothing in these measurements to indicate a direct effect of the methylthiouracil treatment, and the differences are those related to differences in weight. 


\section{Examination of the thyroid glands}

The thyroid glands of the normal control pigs (group I) were of an elongated oval shape, and roughly triangular in cross-section; their medial faces were to a large extent rather closely united by loose connective tissue, so that at first sight the mass of thyroid tissue appeared to consist of a single lobe. These normal glands were brown or buffcoloured, with a rather translucent appearance, and were of firm consistency. Histologically, the acini were well filled with a strongly staining colloid. The epithelial cells were low columnar, cuboidal or flattened in shape. The nucleus stained rather darkly, and, except in the flattened cells, was rounded and occupied the middle part of the cell. The average weight of the thyroid glands of the three control pigs killed after I I weeks of the experiment was $5.2 \mathrm{~g}$, and of two of the three normal pigs killed after a further 8 weeks, $18 \cdot 7 \mathrm{~g}$.

After II weeks of dosage with methylthiouracil, the thyroids of the treated pigs (groups 2 and 3 ) were larger and heavier than those of the untreated pigs. In group 2, the average weight was $30.6 \mathrm{~g}$. (three pigs), and in group $3,30.3 \mathrm{~g}$. (three pigs). The glands were reddened, and fleshy in consistency. Their anterior parts had become considerably separated from each other, while their posterior halves were still more or less closely in contact, so that the thyroid mass now had a winged appearance. Histologically, the glands showed the typical appearance of hyperplasia, not differing noticeably in degree in the two groups. The epithelium was tall columnar, from two to three times the normal height. The nucleus of the epithelial cell was elongated, less darkly staining, and increased in size; some mitotic figures were present. The epithelium showed well-marked papilliform projections, supported by a core of vascular stroma, into the lumen of the enlarged acini, from which the colloid was partly or almost entirely absent; the little colloid that remained generally stained faintly and was vacuolated. Droplets of material, stained red with eosin and resembling colloid, were seen in the cytoplasm of many of the epithelial cells, mainly between the nucleus and the base of the cell. The stroma appeared hyperaemic. (Acevedo et al. (1948) described changes of hyperplasia in the thyroid glands of pigs fed a ration containing $0.25 \%$ thiouracil for 5 I days.)

At the end of the experiment, after 8 weeks of withholding the methylthiouracil, the glands remained larger than normal, the average weight in group 2 being $29.4 \mathrm{~g}$. (three pigs), and in group $3,36.9 \mathrm{~g}$. (two pigs). The gland tissue remained rather redder than normal, and the bilobed appearance of the thyroid mass was still obvious. Microscopically, the acini were well filled with strongly staining colloid, and the epithelium had mostly reverted to the low columnar, cuboidal or flattened type, but the remains of the papilliform projections could still sometimes be seen as slight inward bulges of the acinar walls.

Pigs which received methylthiouracil developed a characteristic wrinkling of the skin. To a much lesser extent, this condition was also noticed in pigs which received high doses of thiourea in Exp. I. Pl. I shows a photograph of this condition. At slaughter sections of skin were removed from the middle of the back from the nine pigs killed after I I weeks of the experiment (six treated and three controls). They were fixed 
in formalin or Cleverdon's, and paraffin sections were prepared and stained with haematoxylin and eosin, van Gieson and orcein. Histological changes were not marked but, on the whole, the cornified layer was thicker in the treated pigs than in the controls, and many of the downward projections of the rete Malpighii were longer and thinner, so that the dermal papillae were more obvious, the connective tissue in them being very open in texture. Around the capillaries just beneath the epithelium of the treated pigs there were more numerous eosinophil polymorphs than in the skin of the controls. Beeson, Andrews, Witz \& Perry (1947) described a condition of severe myxoedema in pigs fed a diet containing $0.1 \%$ thiouracil for 6 weeks, the condition being reversed by withholding the thiouracil and giving thyroprotein.

\section{EXPERIMENT 3. EFFECT OF METHYLTHIOURACIL}

\section{Methods}

Four groups, consisting of six weaners each, 12-13 weeks old at the commencement, were used in this test. The details of management were similar to those in the trial previously described, except that the composition of the diet was changed to the following: wheat feed 40 , barley meal 25 , maize meal 25, white-fish meal $10 \%$. Animals in one of the groups, chosen at random, acted as controls. The other groups received by lot the following daily quantities of methylthiouracil/roo lb. live weight: group 2, heavy dose, $4 \mathrm{~g}$.; group 3 , medium dose, $1.5 \mathrm{~g}$.; group 4 , light dose, $0.5 \mathrm{~g}$.

As the experiment progressed it became obvious that the doses for groups 2 and 3 were too high, and after 8 weeks these treatments were discontinued. By that time most of the pigs in these groups refused to take food, began to lose weight and to look very unthrifty. After the drug supplement was stopped the pigs recovered very quickly. The treatment given to pigs in group 4 was continued for a further 102 days. After $15^{8}$ days on the experiment all the pigs were slaughtered.

\section{Results}

Table 5 gives data for growth and food utilization for the two periods: the first 56 days and the following 102 days. Fig. I shows the rate of growth of the pigs in the four groups throughout the experimental period. It is obvious that at all three levels of dosage the growth was inhibited, and the intake of food reduced. The pigs became scruffy and lethargic. Their general appearance changed, so that they looked stunted but in good fattening condition, and rather rounder than the controls, as if they were blown. It was impossible to determine whether the change in appearance was due to the treatment or whether the retardation of growth per se and the resulting unthriftiness were responsible for it. After the drug supplement was stopped for groups 2 and 3, the pigs began to take more interest in their food, and in about a fortnight were eating normally.

The pigs in group 4, which received $0.5 \mathrm{~g}$./ $100 \mathrm{lb}$. live weight of methylthiouracil for $x 5^{8}$ days gradually developed a condition similar to that observed in groups 2 and 3 after 8 weeks of treatment. Towards the end of the experimental period, it seemed likely that the pigs would not survive if the treatment was continued, and they were slaughtered. 
Table 5. Exp. 3. Mean values for gain in weight, food intake and food utilization of groups of six pigs receiving methylthiouracil

Group 2

Methylthiouracil

\begin{tabular}{|c|c|}
\hline Initial live weight (lb.) ... & $\begin{array}{c}\text { Group } 1 \\
\text { Control } \\
61 \cdot 7\end{array}$ \\
\hline & $\begin{array}{lc}\text { irst } & \text { Last } \\
\text { days } & 102 \text { days }\end{array}$ \\
\hline
\end{tabular}

Final live weight (lb.)

Gain (lb.)

Food consumed (lb.)

Food eaten/lb. live-

weight gain (lb.)

Refusals

Occasions

Amount (lb.)

Percentage of food given

- One pig slaughtered 3 days before the rest.

live weight

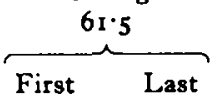

$\begin{array}{rr}127.0 & 265.2 \\ 65.3 & 138.2 \\ 216.8 & 628.9 \\ 3.3 & 4.5\end{array}$

$102 \cdot 2$

$40 \cdot 7$

I 5 I' 9

$3 \cdot 8$

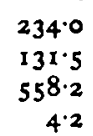

$\begin{array}{rr}0.7 & 9.7 \\ 1.1 & 16.4\end{array}$

$1 \cdot 1$

$40 \cdot 0$

$23 \cdot 1$

$13 \cdot 2$
Group 3

Methylthiouracil Methylthiouracil

$4 \mathrm{~g} .1100 \mathrm{lb}$. $\quad \mathrm{T} .5 \mathrm{~g} . / 100 \mathrm{lb}$.

56 days 102 days live weight 60.8

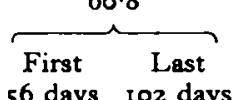

56 days 102 days

$\begin{array}{rr}101.3 & 225.8 \\ 40.5 & 124.5 \\ 149.8 & 539.2\end{array}$

I $49 \cdot 8$

$3 \cdot 7$

$539 \cdot 2$

$4 \cdot 3$

$\begin{array}{ll}38 \cdot 7 & 40.5 \\ 24.1 & 35.1\end{array}$

$13.8 \quad 6.2$

+ For five pigs only.

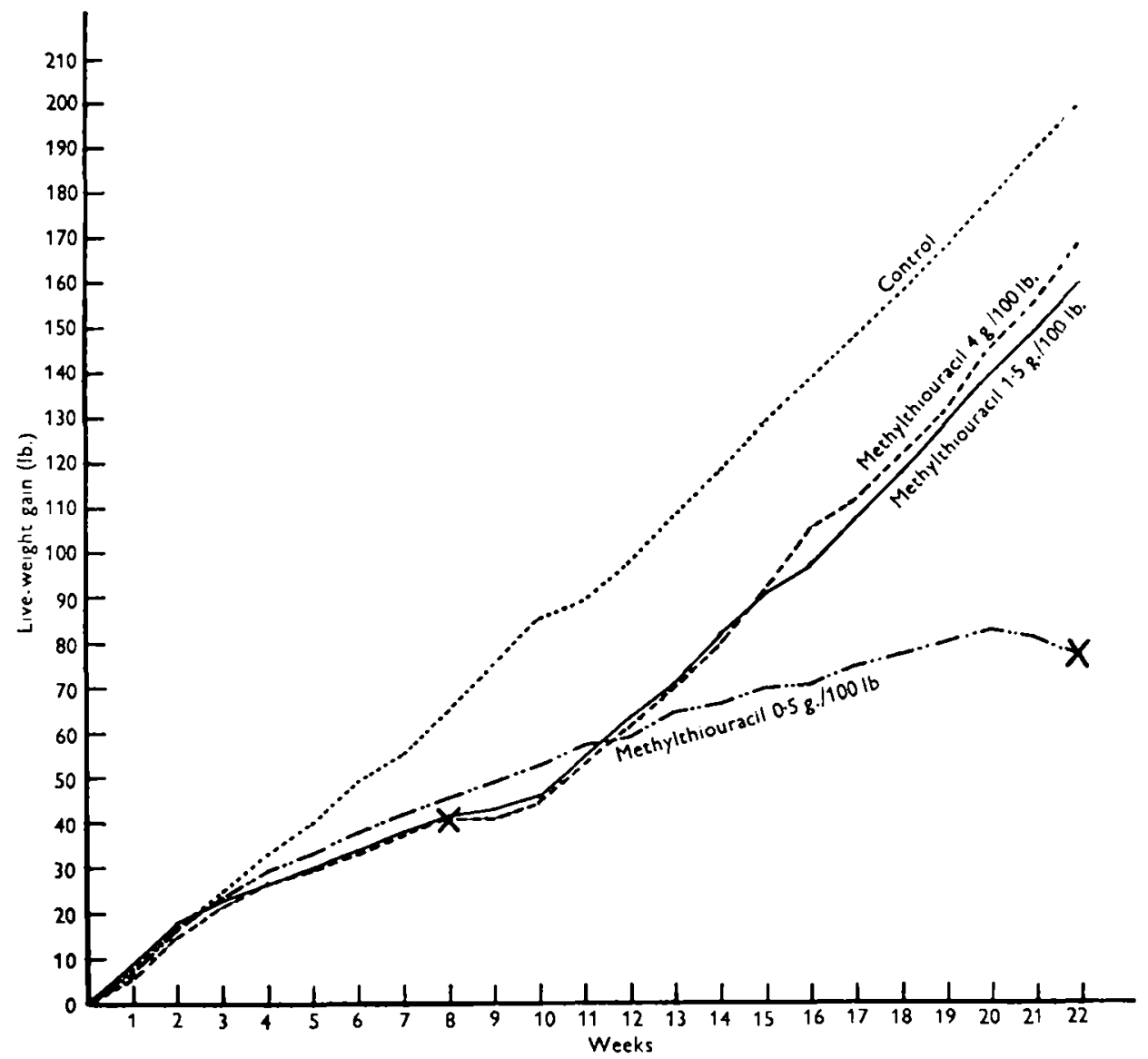

Fig. 1. Exp. 3. Mean individual live-weight gains for groups of six pigs. . . • control pigs; - - , pigs which received daily $4 \mathrm{~g}$. methylthiouracil/100 lb. live weight for 8 weeks; —, pigs which received daily I.5 g. methylthiouracil/100 lb. live weight for 8 weeks; - . - , pigs which received daily $0.5 \mathrm{~g}$. methylthiouracil/100 lb. live weight for 22 weeks; $\times$, methylthiouracil discontinued. 
One pig in group 4 (no. 2733) behaved differently from the rest. It weighed at the commencement of the trial $64 \mathrm{lb}$, and its control litter-mate, pig no. $2734,62 \mathrm{lb}$. Table 6 gives details of their growth and food consumption for fortnightly intervals. Fig. 2 shows the growth curves of the two pigs. It can be seen from the table and the figure that for the first 8 weeks the treated pig grew at a normal rate. During the early

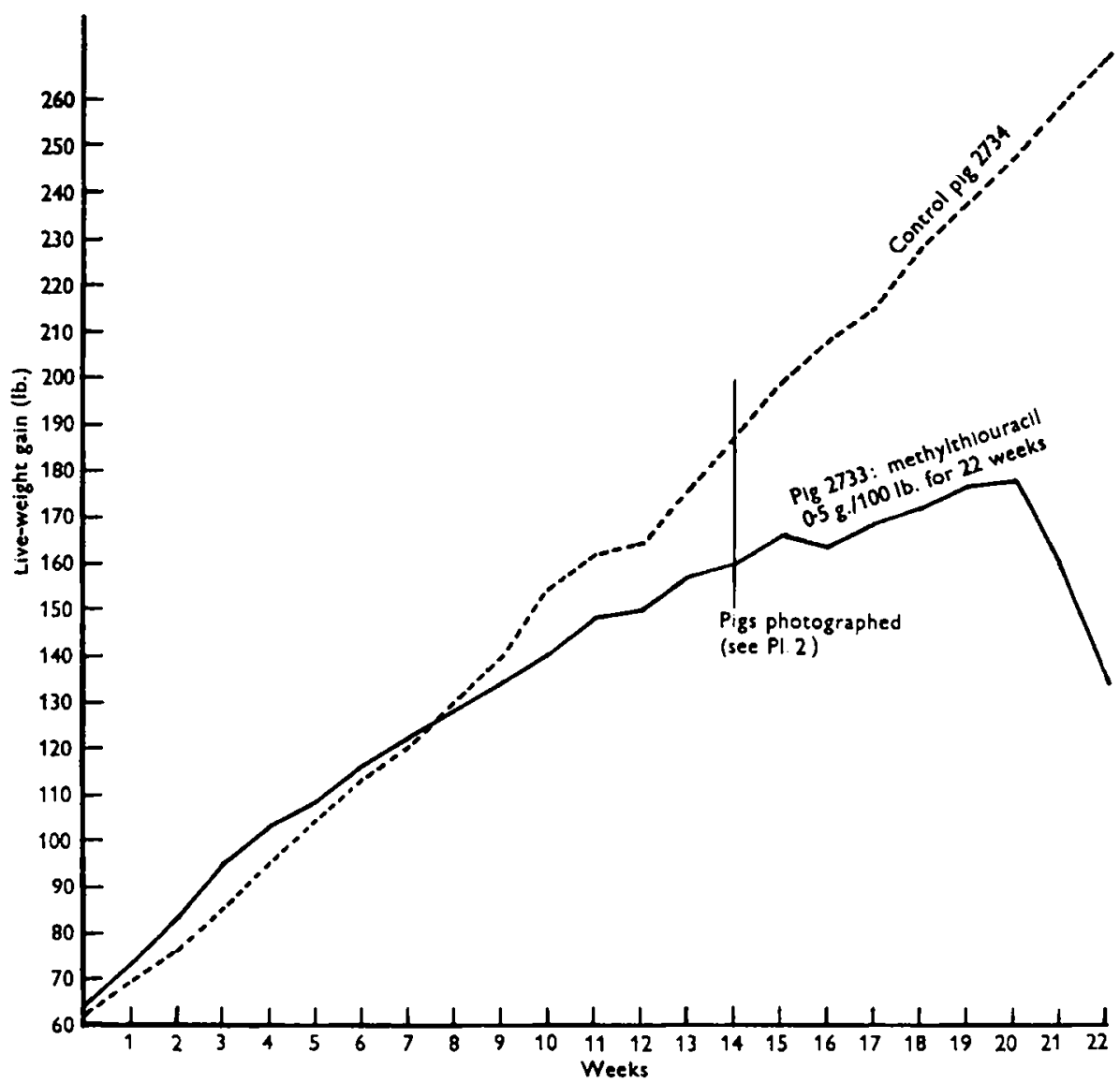

Fig. 2. Exp. 3. Growth curve of pig no. 2733 which received 0.5 g. of methylthiouracil/100 lb. live weight for 22 weeks compared with that of its litter-mate control, pig no. 2734 (see text, this page).

part of this period it was actually growing faster and utilizing its food more efficiently than the control. Already at this stage its appearance was slightly different from that of the control pig. The pig continued to grow, but at a slightly reduced rate, and at the end of the fourteenth week, the photographs in Pl. 2 were taken. It was then of the lard type as against the bacon type of its control mate. It was much shorter, deeper, more compact, standing squarely on medium-short legs. It was uniform in width from the shoulders to the base of the hams. Its side lines were fairly straight, and the width of back and loin was carried uniformly to the belly line. The fat covering appeared uniform and deep. The pig's behaviour was similar to that found in an overdone condition 
of a typical lard-type pig. It was flabby, unable to move about with ease and very lazy. Except for the short periods of feeding it hardly ever got up, and if forced to do so it would immediately lie down when the provocation ceased.

Table 6. Gain in weight, food intake, food utilization and carcass measurements of pigs nos. 2733 and 2734 (see text, p. 181)

\begin{tabular}{|c|c|c|c|c|c|c|}
\hline \multirow{3}{*}{$\begin{array}{c}\text { Fortnightly } \\
\text { periods }\end{array}$} & \multirow{2}{*}{$\begin{array}{l}\text { Live-wt. } \\
\text { gain } \\
\text { (lb.) }\end{array}$} & & \multicolumn{2}{|c|}{ Refusals } & \multirow{2}{*}{$\begin{array}{l}\text { Food } \\
\text { consumed } \\
\text { (lb.) }\end{array}$} & \multirow{2}{*}{$\begin{array}{c}\text { Food } \\
\text { eaten/lb. } \\
\text { live-wt. gain } \\
\text { (lb.) }\end{array}$} \\
\hline & & $\begin{array}{l}\text { given } \\
\text { (lb.) }\end{array}$ & Occasions & $\begin{array}{l}\text { Amount } \\
\text { (lb.) }\end{array}$ & & \\
\hline & & \multicolumn{5}{|c|}{ Pig 2733 (treated with methylthiouracil) } \\
\hline I & 19 & $45^{\prime 2}$ & - & - & $45^{\prime 2}$ & $2 \cdot 3^{8}$ \\
\hline 2 & 19 & $49 \cdot 6$ & 5 & $2 \cdot 9$ & $46 \cdot 7$ & $2 \cdot 46$ \\
\hline 3 & 14 & 53.5 & 5 & $2 \cdot 4$ & $51 \cdot 1$ & $3 \cdot 65$ \\
\hline 4 & 12 & 59.8 & 12 & $7 \cdot 7$ & $52 \cdot x$ & $4 \cdot 34$ \\
\hline 5 & 12 & $62 \cdot 9$ & 12 & 9.5 & 53.4 & $4 \cdot 45$ \\
\hline 6 & 10 & 65.7 & 14 & 9.5 & $56 \cdot 2$ & $5 \cdot 62$ \\
\hline 7 & 10 & $68 \cdot 7$ & 12 & $9 \cdot 3$ & 59.4 & $5 \cdot 94$ \\
\hline 8 & 4 & $70 \cdot 0$ & 14 & 18.0 & $52 \cdot 0$ & 13.00 \\
\hline 9 & 8 & 70.0 & 14 & 20.0 & 50.0 & 6.25 \\
\hline 10 & 6 & $70 \cdot 0$ & 14 & 18.0 & $52 \cdot 0$ & 8.67 \\
\hline I I & -43 & 65.0 & 14 & 43.0 & $22 \cdot 0$ & - \\
\hline
\end{tabular}

Pig 2734 (control)

\begin{tabular}{|c|c|c|c|c|c|c|}
\hline I & 14 & $42 \cdot 8$ & - & 一 & $42-8$ & 3.06 \\
\hline 2 & 18 & $50 \cdot 4$ & - & - & $50 \cdot 4$ & 2.80 \\
\hline 3 & 19 & $59 \cdot 1$ & - & - & $59 \cdot \mathbf{I}$ & $3 \cdot 28$ \\
\hline 4 & 17 & 66.4 & - & - & 66.4 & 3.91 \\
\hline 5 & 25 & $75 \cdot 3$ & - & - & $75 \cdot 3$ & 3.01 \\
\hline 6 & 19 & $80 \cdot 1$ & 4 & 8.0 & $72 \cdot 1$ & $3 \cdot 79$ \\
\hline 7 & 23 & $91 \cdot 0$ & - & - & 91.0 & 3.96 \\
\hline 8 & $2 I$ & $93 \cdot 8$ & - & - & 93.8 & 4.47 \\
\hline 9 & 20 & $97 \cdot 4$ & - & - & 97.4 & 4.87 \\
\hline 10 & 20 & $98 \cdot 0$ & - & 一 & $98 \cdot 0$ & 4.90 \\
\hline I I & 22 & $98 \cdot 0$ & 一 & - & 98.0 & $4: 45$ \\
\hline
\end{tabular}

From the fifteenth to the twentieth week of the experimental period, the pig continued to grow at a very subnormal rate, and finally lost condition rapidly. Getting up appeared to cause it discomfort, and breathing became laboured. Its appetite declined steadily, until eventually it refused food altogether, and was slaughtered. Its normal control litter-mate was slaughtered at the same time.

Table 7 gives details of the carcass measurements of the pigs in group I (controls), group 2 (high dose of methylthiouracil discontinued after 56 days) and group 4 (low dose of methylthiouracil for 158 days). No measurements were taken of carcasses from group 3. In general these average values indicate that methylthiouracil retarded growth. In group 4 the deposition of fat was slightly higher than is normal in pigs of the same length. The measurements of pig no. 2733 are also given in Table 7 , and are of particular interest as they indicate that in this pig the fat layer was excessive in proportion to the other dimensions of the carcass. 


\section{Examination of the thyroid glands}

The average weight of the thyroid glands in the six control pigs was $12 \cdot 1 \mathrm{~g}$. (range $9 \cdot 0-14.8)$; histologically they showed vesicles well filled with colloid. In group 2, which received methylthiouracil for the first 56 days only, the average weight of the thyroid glands was $3 \mathrm{I}^{\cdot} 5 \mathrm{~g}$. (range $26 \cdot 5-38 \cdot 5$ ). The epithelium was not hyperplastic and the vesicles were well filled with colloid. Probably, as a result of previous hyperplasia,

Table 7. Exp. 3. Mean values for carcass measurements of groups of six pigs listed in Table 5, and individual values for pigs nos. 2733 and 2734 listed in Table 6

\begin{tabular}{|c|c|c|c|c|c|}
\hline & $\begin{array}{l}\text { Group I } \\
\text { Control }\end{array}$ & Pig 2734 & $\begin{array}{l}\text { Group } 2 \\
\text { Methyl- } \\
\text { thiouracil } \\
4 \mathrm{~g} \cdot / \mathrm{I} 00 \mathrm{lb} \text {. } \\
\text { live weight } \\
\text { for } 56 \text { days }\end{array}$ & $\begin{array}{c}\text { Group } 4 \\
\text { Methyl- } \\
\text { thiouracil } \\
0.5 \mathrm{~g} . / 100 \mathrm{lb} \text {. } \\
\text { live weight } \\
\text { for } 158 \text { days }\end{array}$ & Pig 2733 \\
\hline Final live weight (lb.) & $262 \cdot 2$ & 270 & 232.5 & $137 \cdot 3$ & 135 \\
\hline Hot carcass weight (lb.) & $207 \cdot 2$ & 209 & $177 \cdot 8$ & $105 \cdot 5$ & 106 \\
\hline Length of body cavity (mm.) & 819.5 & 825 & $790 \cdot I$ & $643 \cdot 7$ & 658 \\
\hline Length of hind leg (mm.) & $631 \cdot 5$ & 637 & $596 \cdot 5$ & $492 \cdot 7$ & 495 \\
\hline $\begin{array}{l}\text { Thickness of back fat }(A) \\
\text { (mm.) }\end{array}$ & $63 \cdot 5$ & $5^{8}$ & $54 \cdot 2$ & $43 \cdot 5$ & $5^{1}$ \\
\hline $\begin{array}{l}\text { Thickness of back fat }(B) \\
(\mathrm{mm} .)^{*}\end{array}$ & $33 \cdot 5$ & 30 & $29 \cdot 2$ & $23 \cdot 0$ & 33 \\
\hline $\begin{array}{l}\text { Thickness of rump fat } \\
\left(C_{1}, C_{2}, C_{3}\right)(\mathrm{mm} .)^{*}\end{array}$ & $4 \mathrm{I} \cdot 6$ & $3^{8}$ & $35^{\circ} \circ$ & $20 \cdot 1$ & 29 \\
\hline Weight of thyroid (g.) & $12 \cdot 1$ & $I I \cdot 8$ & $3 I \cdot 5$ & $46 \cdot 5$ & 43.0 \\
\hline
\end{tabular}

the acini were on the average slightly larger than in the control pigs. In group 4, which had received methylthiouracil for $15^{8}$ days, the average weight of the thyroid glands was $46 \cdot 5 \mathrm{~g}$. (range $33^{\circ} 0-59^{\circ}$ ). 'They showed a well-marked diffuse epithelial hyperplasia, and little, faintly staining, colloid remained. The thyroid gland of pig no. 2733 of group 4 weighed $43^{\circ} \circ \mathrm{g}$., as compared with $\mathrm{Ir} .8 \mathrm{~g}$. in the control litter-mate, pig no. 2734 .

\section{EXPERIMENT 4. EFFECT OF METHYLTHIOURACIL}

\section{Methods}

Six pairs of litter-mates, weighing on the average $170 \mathrm{lb}$. at the commencement of the test, were used. One pig in each pair, chosen by lot, acted as a control, while the other received daily methylthiouracil at the rate of $3 \mathrm{~g} / / 100 \mathrm{lb}$. live weight. Experimental routine was similar to that in the previous experiment. The test lasted 5 weeks.

\section{Results}

Table 8 gives details of growth, food intake and food utilization. It can be seen that the rate of growth of the treated pigs was slightly slower but that they utilized the food a little more efficiently than the controls. Two treated pigs refused some food nearly every day and the remaining four started to refuse food only during the last 2 weeks of the experimental period. It was obvious that a continuation of the treatment would have resulted in increased food refusals by the treated animals. 


\section{DISCUSSION}

The results of the four experiments reported here show that in practical pig feeding there is no advantage to be gained from including a small proportion of antithyroid drugs in the feed.

Thiourea has such a bitter taste that animals refuse food containing even a small amount of it. Even less than $0.2 \mathrm{~g}$. daily of thiourea (about $0.015 \%$ of the ration) proved objectionable to young pigs. To such a small amount pigs get accustomed fairly

\section{Table 8. Exp. 4. Gain in weight, food intake and food utilization of pigs} receiving methylthiouracil

(Mean initial weight $170 \mathrm{lb}$. Length of experimental period, 5 weeks.)

\begin{tabular}{|c|c|c|c|c|c|c|}
\hline \multirow[b]{2}{*}{ Pig no. } & \multirow{2}{*}{$\begin{array}{l}\text { Meal } \\
\text { given } \\
\text { (lb.) }\end{array}$} & \multicolumn{2}{|c|}{ Refusals } & \multirow{2}{*}{$\begin{array}{c}\text { Meal } \\
\text { consumed } \\
\text { (lb.) }\end{array}$} & \multirow{2}{*}{$\begin{array}{l}\text { Live-wt. } \\
\text { gain } \\
\text { (lb.) }\end{array}$} & \multirow{2}{*}{$\begin{array}{c}\text { Food } \\
\text { eaten/lb. } \\
\text { live-wt. gain } \\
\text { (lb.) }\end{array}$} \\
\hline & & Occasions & $\begin{array}{l}\text { Amount } \\
\text { (lb.) }\end{array}$ & & & \\
\hline \multicolumn{7}{|c|}{ Group I. Control } \\
\hline$I$ & $239 \cdot 3$ & I & 0.7 & 238.6 & 47 & 5.08 \\
\hline 2 & $239 \cdot 3$ & I & 0.7 & 238.6 & 60 & 3.98 \\
\hline 3 & $239 \cdot 3$ & - & - & $239 \cdot 3$ & 52 & $4 \cdot 60$ \\
\hline 4 & $239 \cdot 3$ & 一 & - & $239 \cdot 3$ & 52 & 4.60 \\
\hline 5 & $239 \cdot 3$ & I & $\mathrm{I} \cdot 4$ & $237 \cdot 9$ & 59 & 4.03 \\
\hline 6 & $236 \cdot 9$ & 一 & - & 236.9 & 53 & 4.46 \\
\hline Total & 1433.4 & 3 & $2 \cdot 8$ & $1430 \cdot 6$ & 323 & $26 \cdot 75$ \\
\hline Mean & $238 \cdot 9$ & 0.5 & 0.47 & $238 \cdot 4$ & $53 \cdot 83$ & $4: 46$ \\
\hline \multicolumn{7}{|c|}{ Group 2. Methylthiouracil $3 \mathrm{~g} . / 100 \mathrm{lb}$. live weight } \\
\hline I & $236 \cdot 6$ & 35 & $6 I \cdot 91$ & 174.69 & 34 & $5 \cdot 1_{4}$ \\
\hline 2 & $239 \cdot 3$ & 13 & $39 \cdot 2$ & $200 \cdot 10$ & 49 & 4.08 \\
\hline 3 & $238 \cdot 7$ & 10 & $18 \cdot 1$ & $220 \cdot 6$ & 50 & 4.41 \\
\hline & & I & 0.7 & $238 \cdot 6$ & 59 & 4.04 \\
\hline 5 & $239 \cdot 3$ & 9 & $18 \cdot 2$ & $221 \cdot I$ & 59 & 3.75 \\
\hline 6 & $236 \cdot 2$ & 29 & $52 \cdot 25$ & 183.9 & 47 & 3.91 \\
\hline Total & $1429^{\circ} 4$ & 97 & $190.3^{6}$ & 1238.99 & 298 & $25 \cdot 33$ \\
\hline Mean & $238 \cdot 2$ & $16 \cdot 2$ & $31 \cdot 73$ & $206 \cdot 49$ & $49 \cdot 67$ & $4 \cdot 22$ \\
\hline
\end{tabular}

quickly, but at such a low level the supplement has no effect on the growth rate or the food utilization of the animals (cf. Table I, group 4). When the dose of thiourea was larger, $0.75,1.5$ or $3.0 \mathrm{~g} . / 100 \mathrm{lb}$. body-weight, the amount of food refused by the pigs increased correspondingly, and the rate of growth was considerably retarded. The latter effect was obviously due to the refusal of the pigs to consume food containing this amount of thiourea. When drenched with the drug the animals showed no adverse effects, but if the same quantity was added to the food they rejected it, partly or wholly. The retardation in the rate of growth of pigs receiving a diet containing thiourea was so great as to make any saving in meal required per lb. live-weight gain an uneconomical proposition. Whether the slight improvement observed in the utilization of food was due to physiological effects of the drug on the metabolism of the pig it is not possible to say, because the whole development of the animal became abnormal by effects mainly associated with the unpalatability of the drug. 
With methylthiouracil the pigs also refused a portion of their food, the amount refused being influenced by the level of the dose: the higher the dose the larger were the refusals. However, with methylthiouracil the refusals could not be wholly attributed to unpalatability, as with thiourea. With the smaller doses it appeared that a cumulative effect caused loss of appetite, as a considerable time elapsed from the beginning of the test before the first refusals of food were recorded, and it also took the treated pigs much longer to recover once the drug supplement was withdrawn. The drug obviously had a cumulative retarding effect on growth; but once the treatment was stopped the pigs very soon resumed normal growth. There was some indication that pigs receiving the treatment required less food per lb. live-weight gain than the control animals, but the difference was not large enough to be of value in practical pig feeding. There would be no advantage in using a potent drug to save a small proportion of food, when by so doing rate of growth and economy of fattening would be adversely affected. It has been suggested that the drug should only be used after the period of rapid growth has ended. In the bacon pig such a period does not really exist. Our results (Exp. 4) indicate that there is no advantage in treating the pigs with antithyroid drugs for a few weeks before they are sent to slaughter.

The case of pig no. 2733 deserves special mention, because, in our opinion, it has an important bearing on the future application of synthetic endocrine-active substances in animal husbandry. It points to the importance of striking a balance between exogenous stimulants and the active substances within the body. Such a balance was possibly struck by chance with pig no. 2733. Here an individual pig responded dramatically to a treatment to which other pigs responded only partly, if at all. At one stage the pig showed all the symptoms which might be expected to follow the feeding of thyroid-inhibiting substances to a pig of a type suitable for bacon production. Its metabolic rate was lowered, growth rate was slowed up, food consumption was reduced, food utilization was improved, and the conformation of the pig gradually changed from that of a bacon-type to that of a lard-type pig. Eventually the pig succumbed to the treatment, possibly because its endocrine balance became disturbed. It is, however, possible that the sudden change in response to the treatment was the result of the cumulative action of a potent drug, administered in a dosage adjusted to the pig's live weight.

No changes in the carcass quality were observed that could be attributed to thiourea except those associated with the retardation of growth. The carcasses from treated pigs were smaller than those from control litter-mates slaughtered at the same time. With methylthiouracil there was an indication that the treated pigs became shorter, rounder, fatter and lower on their legs, but the evidence was not conclusive, except with pig no. 2733 , already mentioned.

\section{SUMMARY}

I. The possibility was investigated of influencing favourably food utilization and carcass quality of pigs by the addition of antithyroid drugs to the diet.

2. With thiourea, owing to its bitter taste, the pigs refused much food with consequent retardation of growth. 
3. No detrimental effects were noted when similar doses of the drug were given as a drench.

4. The observed changes in carcass quality could be attributed to the altered growth rate.

5. Methylthiouracil also affected the appetite and the growth rate of some pigs. This effect, apparently cumulative, could not be attributed solely to the unpalatability of the drug.

6. One pig receiving methylthiouracil changed from the bacon to the lard type of conformation and there was an indication that other pigs become shorter, rounder, fatter and lower on their legs than controls not receiving the drug.

7. Though food utilization was slightly improved with some pigs, the effects of the drugs on appetite and growth would make their use in pig feeding uneconomical.

We wish to thank the directors and employees of Messrs M. Venner and Sons Ltd., Bacon Curers, Reading, for allowing us the facilities for, and providing every possible help in, obtaining material after slaughter. Our thanks are also due to $\mathrm{Mr} \mathrm{N}$. Gruber, who prepared the photographs.

\section{REFERENCES}

Acevedo, R., Schweigert, B. S., Pearson, P. B. \& Dahlberg, F. I. (1948). F. Anim. Sci. 7, 214.

Andrews, F. N., Beeson, W. M., Barrick, E. R. \& Harper, C. (1947). F. Anim. Sci. 6, 3.

Andrews, F. N. \& Schnetzler, E. E. (1946). Poult. Sci. 25, 124.

Astwood, E. B. (1943). F. Pharmacol. 78, 79.

Beeson, W. M., Andrews, F. N. \& Brown, P. T. (1947). F. Anim. Sci. 6, 16.

Beeson, W. M., Andrews, F. N., Witz, H. L. \& Perry, T. W. (1947). F. Anim. Sci. 6, 482.

Braude, R. \& Foot, A. S. (1942). Y. agric. Sci. 32, 70.

Charipper, H. A. \& Gordon, A. S. (1947). Vitamins and Hormones, 5, 274.

Davidson, H. R., Hammond, J., Swain, J. B. \& Wright, N. L. (1936). Pig Breed. Anmu. 16, 49.

Glazener, E. W. \& Jull, M. A. (1946). Poult. Sci. $25,236$.

Hammond, J. \& Murray, G. N. (1937). F. agric, Sci. 27, 394.

Kempster, H. L. \& Turner, C. W. (1945). Poult. Sci. 24, 94.

Mackenzie, C. G. \& Mackenzie, J. B. (1943). Endocrinology, 32, 185.

McMillen, W. N., Reineke, E. P., Bratzler, L. J. \& Francis, M. J. (1947). Э. Anim. Sci. 6, 305.

Mixner, J. P., Reineke, E. P. \& Turner, C. W. (1944). Endocrinology, 34, I 68.

Muhrer, M. E. \& Hogan, A. G. (1945). Proc. Soc. exp. Biol., N. Y., 60, 211.

Vander Noot, G. W., Reece, R. P. \& Skelley, W. C. (1947). F. Anim. Sci. 6, 12.

Vander Noot, G. W., Reece, R. P. \& Skelley, W. C. (1948). F. Anim. Sci. 7, 84.

Willman, J. P., Loosli, J. K. \& Klosterman, E. W. (1946). Rep. Cornell agric. Exp. Sta. no. 59, p. 103.

\section{EXPLANATION OF PLATES}

Pl. 1. Characteristic wrinkling of the skin in pigs receiving high doses of thiourea or methylthiouracil

Pl. 2, 1 and 2. Exp. 3. Change in type caused by treatment with methylthiouracil. Pig no. 2733 (right) compared with its litter-mate control pig no. 2734 (see text). 
R. BRAUDE AND E. COTCHIN. ANTITHYRoId DRLGS IN PIg fatteNiNg

Plate I

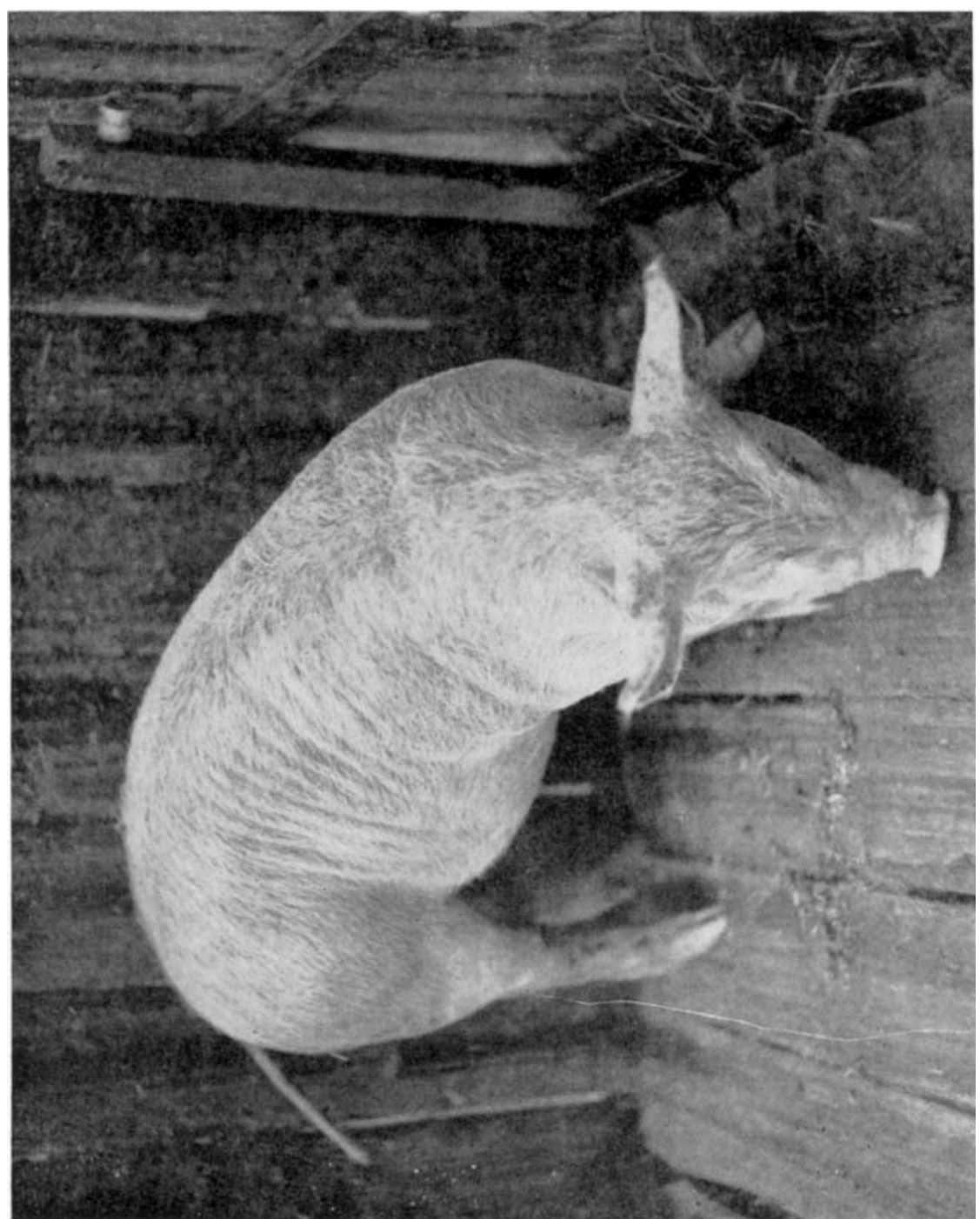

British Yournal of Nutrition, Vol. 3, Nos. 2 and 3 
R. BRAUDE AND E. COTCHIN. ANTITHYRoId DRUGS IN PIG FATTENING

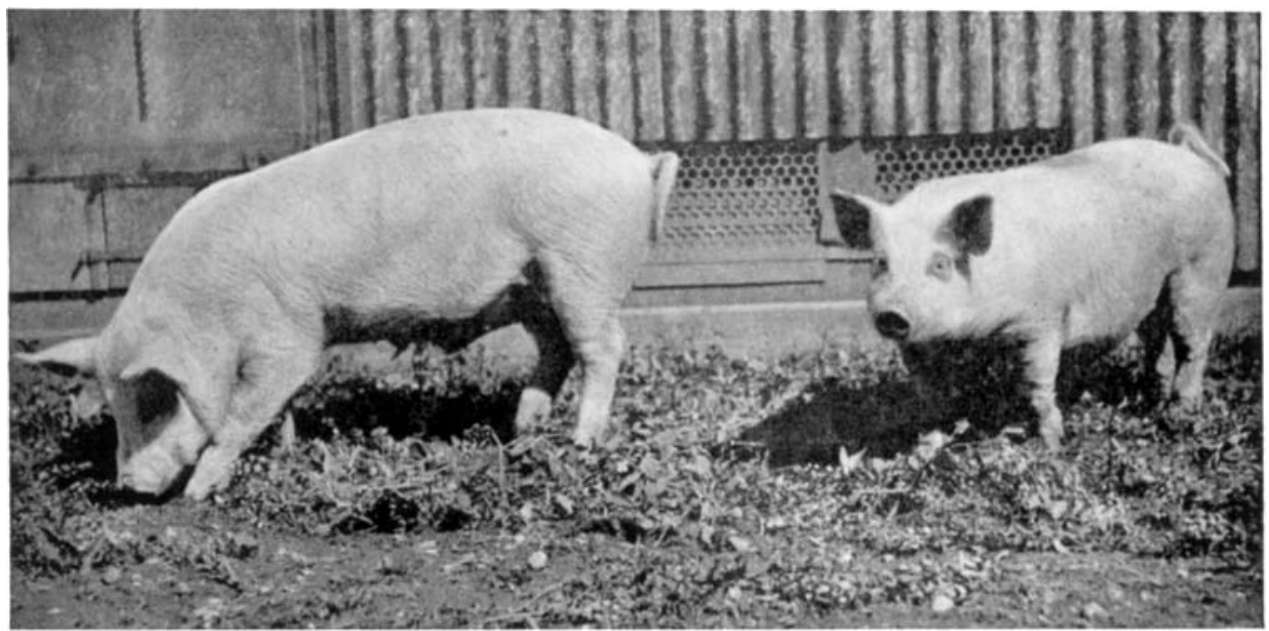

$\mathbf{I}$

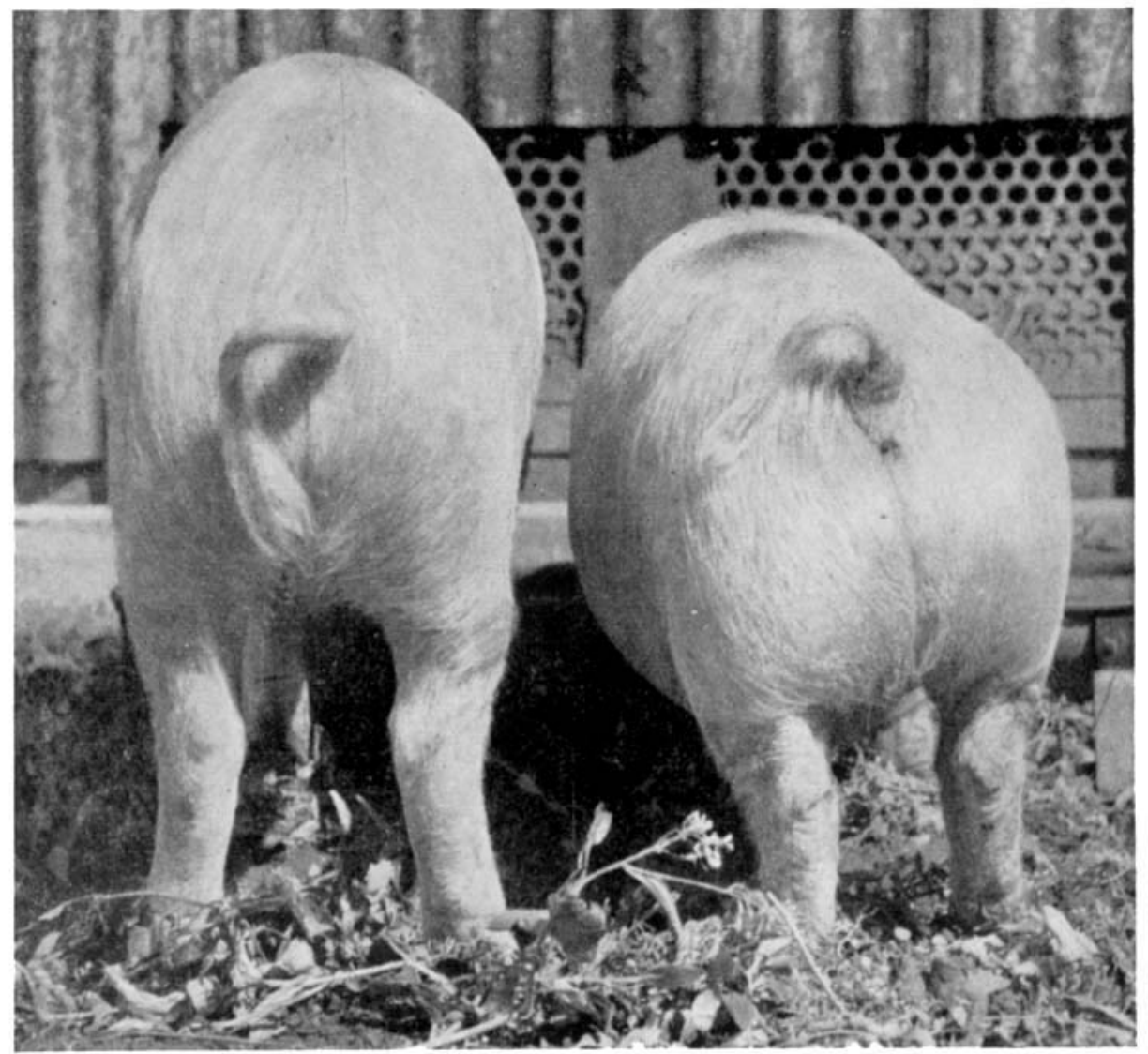

2

British fournal of Nutrition, Vol. 3 , Nos. 2 and 3 